\title{
TALLGRASS PRAIRIE IN THE WHITEWOOD AREA OF SASKATCHEWAN
}

PAUL M. CATLING and BRENDA KOSTIUK, National Environmental Program, Biodiversity Section, Agriculture and Agri-Food Canada, Saunders Bldg, Central Experimental Farm, Ottawa, ON K1A $0 \mathrm{C} 6$

\section{Introduction}

Today, in the interior of North America there is an extensive north-south band of corn, soybean and other crops. Only a little more than a hundred years ago this was the tallgrass prairie on the eastern edge of the great interior grasslands. Only fragments of this ecosystem remain and most of what is left is seriously threatened. Over much of the area it is not clear where the tallgrass prairie was or what it was like. This is particularly true of its occurrence in Saskatchewan.

The tallgrass prairie was a blend zone of woodlands, savanna and glades, home to remarkable, and now greatly diminished, biodiversity. ${ }^{3,16,19}$ It may have evolved as a major ecosystem as little as 10,000 years ago, ${ }^{19}, 28$ and this recent evolution has been proposed as an explanation for the fact that relatively few species are confined to the tallgrass prairie region. Despite the low endemism in some groups such as ants, ${ }^{28}$ a number of endangered endemic or nearly endemic species are well-known. These include the Regal Fritillary butterfly, 5, 29, 30, 32 Greater PrairieChicken, ${ }^{12}$ Small White Lady's-slipper orchid (Cypripedium candidum) ${ }^{11}$ and the Prairie White Fringed-Orchid (Platanthera praeclara).$^{10}$ We estimate that at least 400 native species of vascular plants occur in the Canadian examples, and this represents approximately $10 \%$ of the native flora of Canada.

The tallgrass prairie type was formerly maintained by a combination of natural fires and fires started by native people to improve hunting, and by the effects of countless bison, ${ }^{18}$ elk and beaver. The natural processes operated together in complex ways. Fires, interrupted by sloughs and river valleys, burned in a broad mosaic pattern, but also created a local mosaic as a result of the patchiness of bison grazing. Smaller grazed patches, 20 to $50 \mathrm{~m}^{2}$, or larger grazed lawns over 400 $\mathrm{m}^{2}$ in size, were less likely to burn due to the loss of fuel to grazing. The year after a fire, bison would graze in the burned patches. The result was a landscape of patches that had been burned, unburned and grazed, or ungrazed for varying periods of time and the patches were forever changing. ${ }^{18}$ Since the burned and grazed patches were relatively small and distances between them, relatively short, recolonization by insects and other organisms susceptible to fire, but often reliant upon it, occurred from adjacent unburned patches. Before 1800,30 to 60 million bison may have occupied the plains of western North America and they played a major role in determining the composition of the ecosystem. Much management of 
prairie by fire has failed to simulate the local fire mosaic and other effects of the interaction between bison and fire. ${ }^{16}$

Today most of the tallgrass prairie region has been converted to farmland and urban development. No major North American ecosystem has been reduced to such an extent. In the absence of fire and grazing, what little uncultivated land was left after conversion of the landscape by European man was subject to succession and soon replaced by woodland. Over much of its previously occupied area, tallgrass prairie is now represented by scattered remnants that amount to less than 1/10th of one percent of the original area. ${ }^{27}$ Considering the likely extent of tallgrass prairie and the area of the ecozones within which it was dominant in Ontario, Manitoba and Saskatchewan, 6, 9, 19, 20, 21, 26, 31 we calculate that the Canadian tallgrass prairie may have extended over as much as $10,000 \mathrm{~km}^{2}$. Based on information from Environment Canada, World Wildlife Fund and other sources, we estimate that less than 1000 hectares is protected. ${ }^{13,33}$

In general, tallgrass prairies are defined as being dominated by the grass, Big Bluestem (Andropogon gerardii), ${ }^{19,}, 20,21,24$ but other species of grass including Yellow Indian Grass (Sorghastrum nutans), Side-oats Grama (Bouteloua curtipendula), Wand Panic Grass (Panicum virgatum), Little False Bluestem (Schizachyrium scoparium) and Prairie Dropseed (Sporobolus heterolepis) are also locally important. ${ }^{4,19,31}$ Any of these grasses may dominate a stand or association within the tallgrass prairie region, ${ }^{19}$ but Big Bluestem is the signature species. Although stands within tallgrass prairie may be dominated by Little False Bluestem, this species alone is not considered an indicator of tallgrass prairie because it is a frequent, and sometimes dominant, component of the mixedgrass prairies farther west.

The distribution of tallgrass prairie along its western edge has been less well studied than other grassland types ${ }^{8}$ and its limits are poorly defined and some of the maps of tallgrass prairie are contradictory. For example, the reference to tallgrass prairie in the description of ecological region 9.2.12, 7 has occasionally led to the inappropriate mapping of tallgrass prairie across Saskatchewan and into Alberta. With a few such exceptions and errors, however, tallgrass prairie has been shown to reach its northwestern limit in Manitoba ${ }^{25}$ where it corresponds to ecoregion 162, the Lake Manitoba Plain. ${ }^{9}$ Although there is reference to rough fescue grasslands, the description of ecoregion 162 does not (surprisingly) refer to tallgrass prairie which was a dominant community in the zone in pre-settlement times. The classical tallgrass prairie region of Canada is represented in the CEC (Commission for Environmental Cooperation) scheme in the third level as 9.2.2 (48. The Lake Agassiz Plain). Tallgrass prairie was not indicated in Radenbaugh's very useful hierarchical classification of vegetation in Saskatchewan's prairie region. ${ }^{23}$

Big Bluestem has been known for many years from at least 30 sites in southeastern Saskatchewan, ${ }^{22}$ and patches of it have been observed along the Souris River, Moose Mountain Creek, Pipestone Creek, Qu'Appelle River and upper Assiniboine River, and north as far as Hudson Bay Junction on the Red Deer River as well as near 
Margo and Saltcoats ( Jim Romo, Plant Ecologist, pers. comm,. and Vern Harms, Plant Systematist, pers. comm., both at University of Saskatchewan). The vegetation of southeastern Saskatchewan may have been a mosaic of northern mixedgrass prairie, fescue prairie and tallgrass prairie, the latter occurring in patches west to about Whitewood and Yorkton. (Jim Romo, pers. comm.).

Although Big Bluestem has been known for decades from many areas in southeastern Saskatchewan, its potential as an indicator of remnant patches of tallgrass prairie in the province has been less widely realized. This recently changed when Hamilton ${ }^{14}$ postulated the presence of more or less continuous tallgrass prairie in parts of southeastern Saskatchewan on the basis of relict populations of host-specific insects that feed on Big Bluestem, Side-Oats Grama and Prairie Dropseed. His results suggest that these patches were not just a result of seeds that had blown in, but that they were relicts of an ecosystem. Hamilton's work suggested that tallgrass prairie extended $400 \mathrm{~km}$ northwest of this generally accepted limit. This suggestion has led to a number of questions. How extensive was this tallgrass prairie? Was it an unusual kind of tallgrass prairie? Are there any substantial remnants left? A preliminary investigation was undertaken to begin to answer these questions.

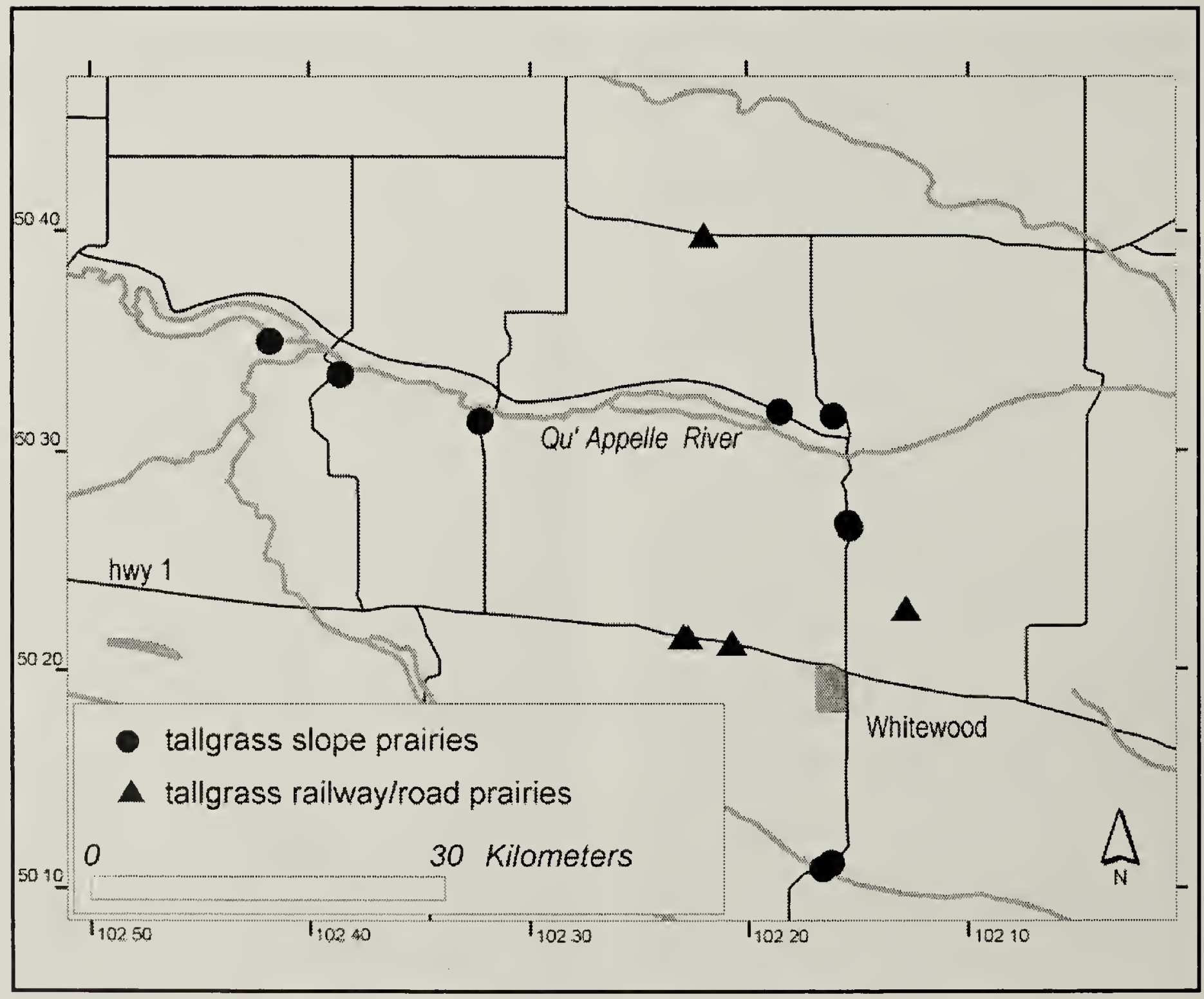

Figure 1. Tallgrass prairie slopes (dots) and prairies on plateaus along railways and roads (triangles) visited in the vicinity of Whitewood, Saskatchewan in June 2005. 


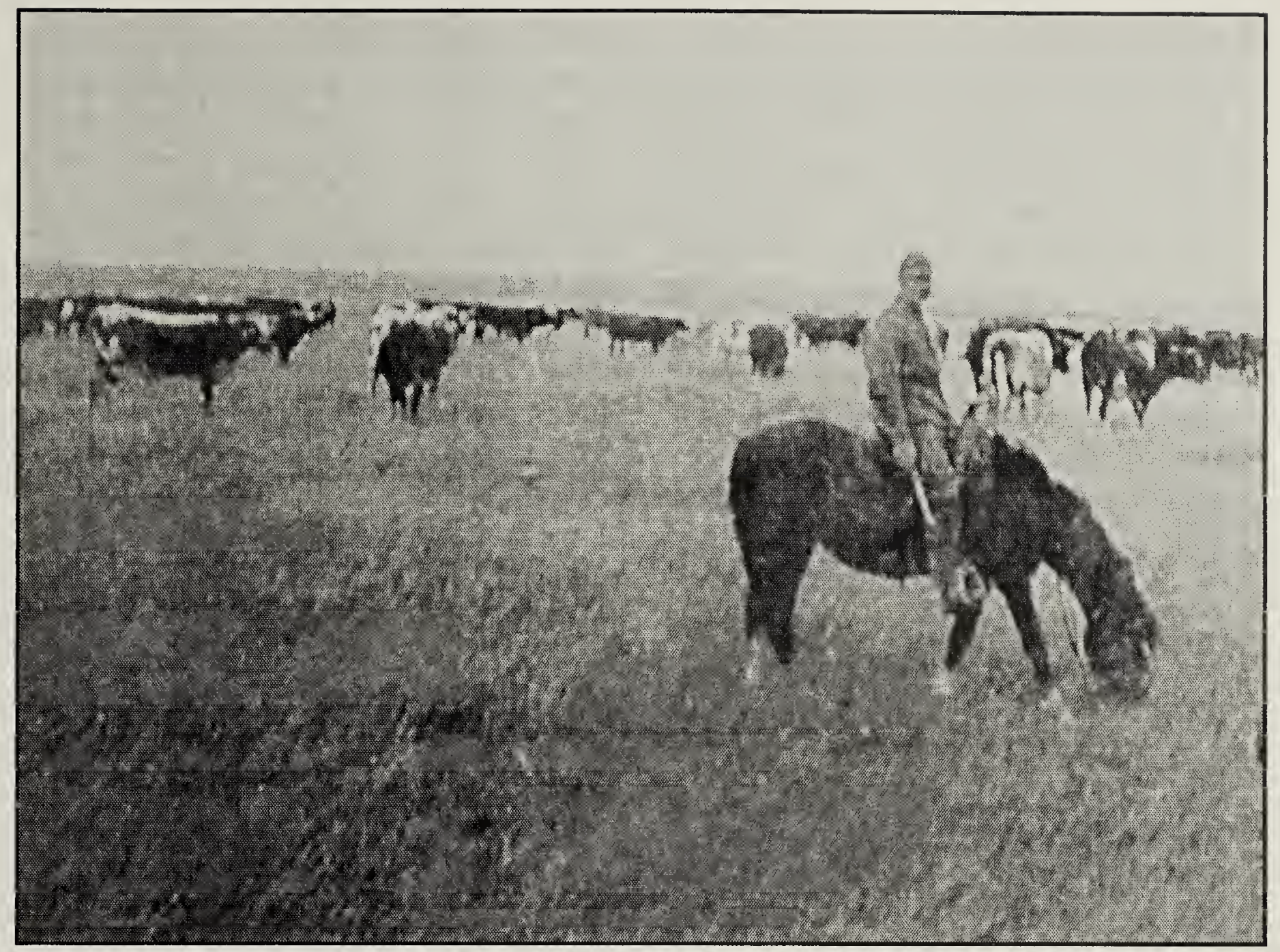

Figure 2. This 1879 photo shows the prairie area south of Whitewood during a cattle drive from Whitewood south to Moose Mountain Creek. Photo provided by George Chopping of Whitewood.

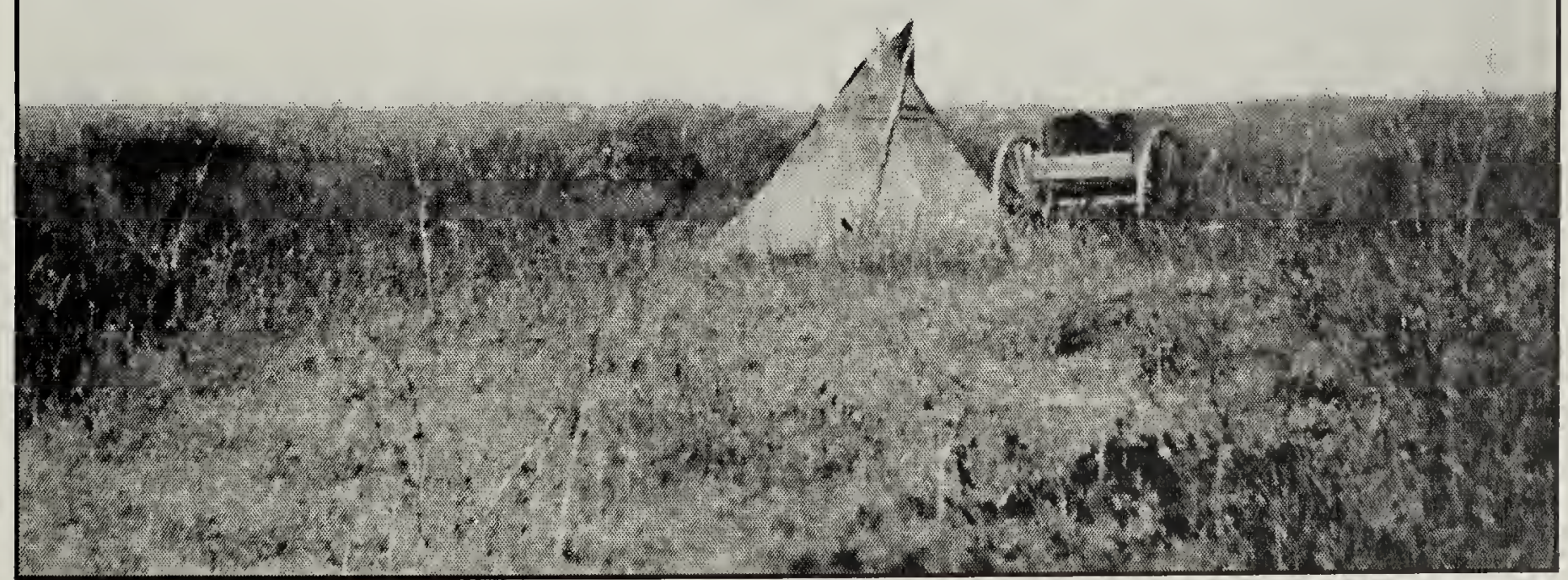

Figure 3. Another 1879 photo from an old album had written below it: "The Indians generally pitched their teepees on the prairie about $1 / 2$ mile north of Whitewood." Photo provided by George Chopping of Whitewood. 


\section{Methods}

A survey of tallgrass prairie remnants in the area around Whitewood, a town approximately $65 \mathrm{~km}$ west of the Manitoba border on Hwy 1 (Figure 1), was undertaken from June $6-15,2005$. We located tallgrass prairie by locating patches of the signature species, Big Bluestem, which was evident as dead stems of the previous year. Three searching strategies were employed to find patches: (1) driving a variety of roads, (2) walking and driving along railways, (3) finding, with the help of local farmers, land that was unbroken. The common and scientific names used in this article were derived from Kartesz and Meachum. ${ }^{17}$

\section{Historical Perspectives}

In the late 1800 s, prairie occurred throughout the region of Whitewood.
Photos from this period show that the grass is relatively short (Figure 2). Mature stands of trees were scarce and Aspen Poplar (Populus tremuloides) stands were maintained as scrub or saplings by the frequent fires (Figure 3 ). Whitewood was named for a unique stand of Birch (Betula papyrifera) or Aspen Poplar (both of which can have white trunks). Early settlers travelled from Regina to Moose Mountain, south of Whitewood, to get firewood for the winter, often enduring incredible hardship. The days of this firemaintained ecosystem were numbered. By the early 1900 s much of the land had been converted to fields of crops and pasturelands often "improved" with introduced European grasses. " The landscape today is mostly croplands with scattered sloughs and trees and frequent groves

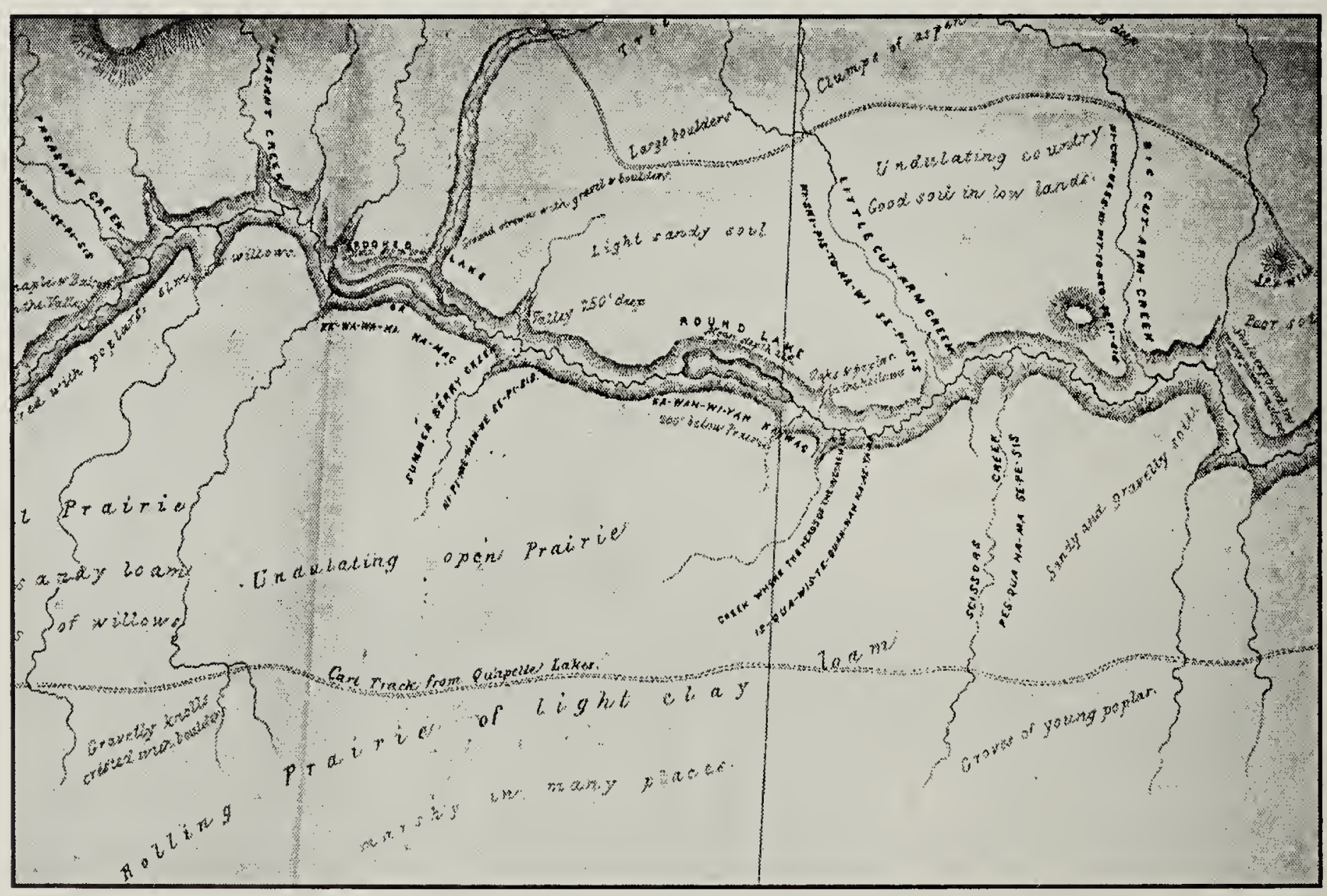

Figure 4. In this portion of Henry Youle Hind's 1858 map much of the area around Whitewood (then part of Rupert's Land) is clearly identified as prairie. Whitewood is on the cart track near the word "loam" to the right of and below centre. Provided by Blaine Coleman. Source: Hind, H. Y. 1859. Territoire du Nord-Ouest, John Lovell, Toronto. 
of Aspen Poplar. Although confirmed to be predominant in pre-settlement times (Figure 4), it is hard to imagine prairie in this area today.

\section{Field Survey Results}

We soon learned that Big Bluestem was most likely to be found along river valleys, but a few small patches were also located along the railways and roadsides on the rolling prairie plateau (Figure 1). In all cases these essentially flat railway and roadside patches were near or under Aspen Poplars. All were very small, being less than 0.1 acre, and most were developing into woodland. Along the roads and railways, relicts of both fescue prairie and mixedgrass prairie dominated by Little Bluestem were much more abundant and the unbroken lands were either dominated by introduced species or by impressive mixedgrass associations. The few tallgrass prairie patches were rich in native species and appeared to be authentic remnants that were very much like the main northern portion of continuous tallgrass prairie. Obvious early summer plants in these remnants included several species with yellow flowers such as Hoary Pucoon (Lithospermum canescens, Figure 5), Heart-leaf Alexanders (Zizia aptera) and Yellow Lady's-slipper (Cypripedium parviflorum var. pubescens). The yellow color of their flowers may be an advantage in sharing pollinators. A few white-flowered species were also frequent, including Cream Vetchling (Lathyrus ochroleucus) and Canadian White Violet (Viola canadensis var. rugulosa). Gray Willows (Salix bebbiana) were present at a number of the locations, suggesting mesic conditions.

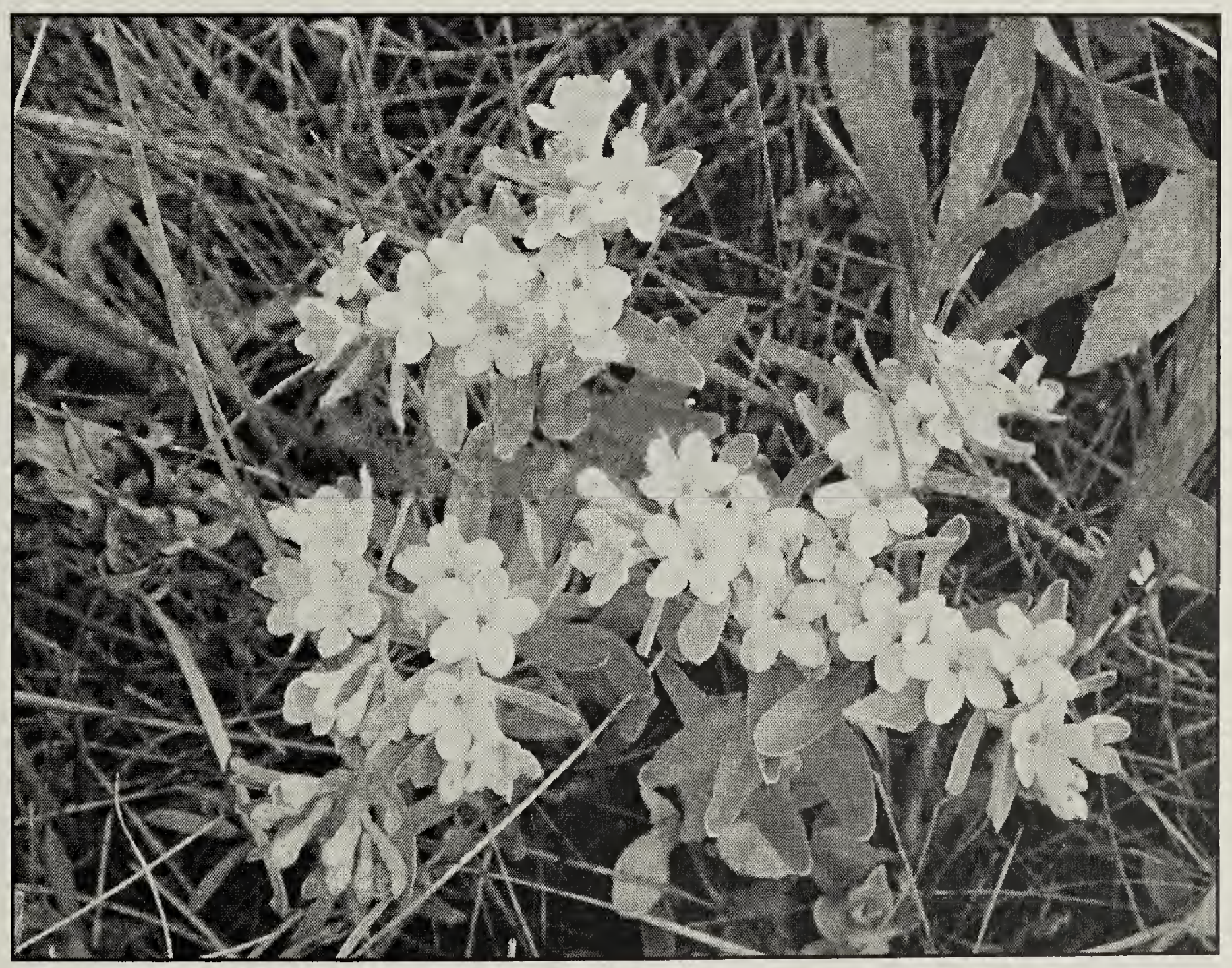

Figure 5. Hoary Pucoon west of Whitewood, June 2005.

P.M. Catling 


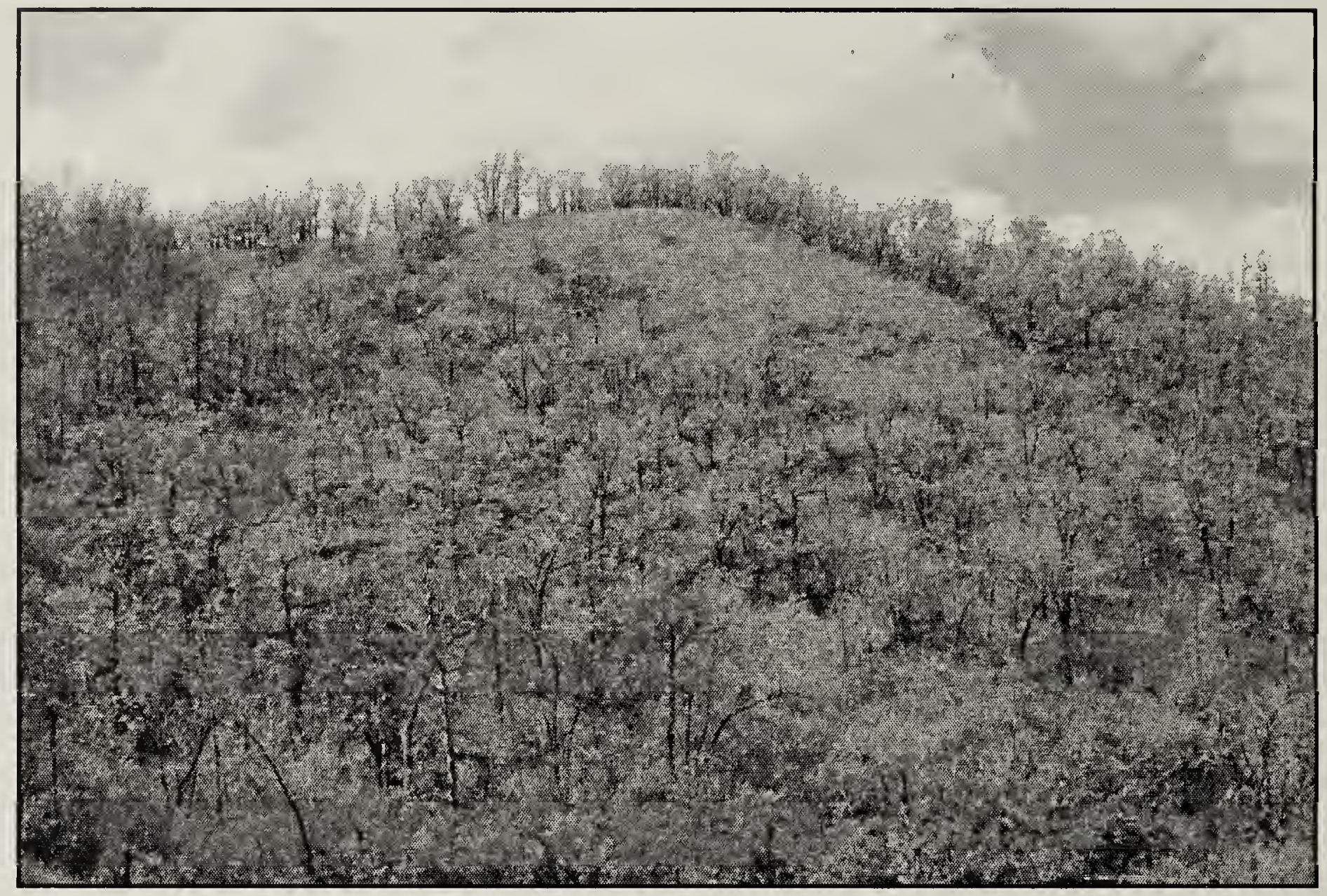

Figure 6. Tallgrass prairie (open area in upper middle) on a south-facing slope of a creek draining into the Qu'Appelle River north of Whitewood, June 2005. In pre-settlement times, the tallgrass prairie would probably have been predominant in this area which has more recently closed in with Bur Oak (Quercus macrocarpa Michx.) woodland and savanna.

P.M. Catling

The composition of tallgrass prairie on river valley slopes differed from that on plateaus. On the larger slope sites $(0.5$ to 2 acres, Figures 6,7$)$ the species noted above tended to be less frequent and more or less confined to the lower levels. Higher on the slope, conditions become drier and other graminoids increased in frequency including some typical of drier prairie such as Blue Grama or Eyebrow Grass (Bouteloua gracilis), porcupine grasses (Hesperostipa spp.) and Thread-Leaf Sedge (Carex filifolia). Over much of the area where tallgrass prairie remnants exist, it was unusual to see these species growing beside Big Bluestem. Many of the distinctive herbaceous species present were also characteristic of the drier mixedgrass prairie farther west. Among the spring flowering herbs of the tallgrass prairie slope sites were: White Wild Onion (Allium textile), Red Windflower (Anemone multifida), Holboell's Rockcress (Arabis holboellii var. secunda), Oval-Leaf Milkweed (Asclepias ovalifolia), Green Comet Milkweed (Asclepias viridiflora), Cock's-Head (Astragalus agrestis), Two-Groove Milk-Vetch (Astragalus bisulcatus var. bisulcatus), Laxmann's Milk-Vetch (Astragalus laxmanii var. robustior), Missouri Milk-Vetch (Astragalus missouriensis), Looseflower Milk-Vetch (Astragalus tenellus), Great Plains Indian Paintbrush (Castilleja sessiliflora, see front cover photograph), Early Yellow Locoweed (Oxytropis sericea var. speciosa), Large Indian-Breadroot (Pediomelum esculentum, Figure 8), Lamb-tongue Ragwort (Senecio integerrimus), RedLine Beardtongue (Penstemon 


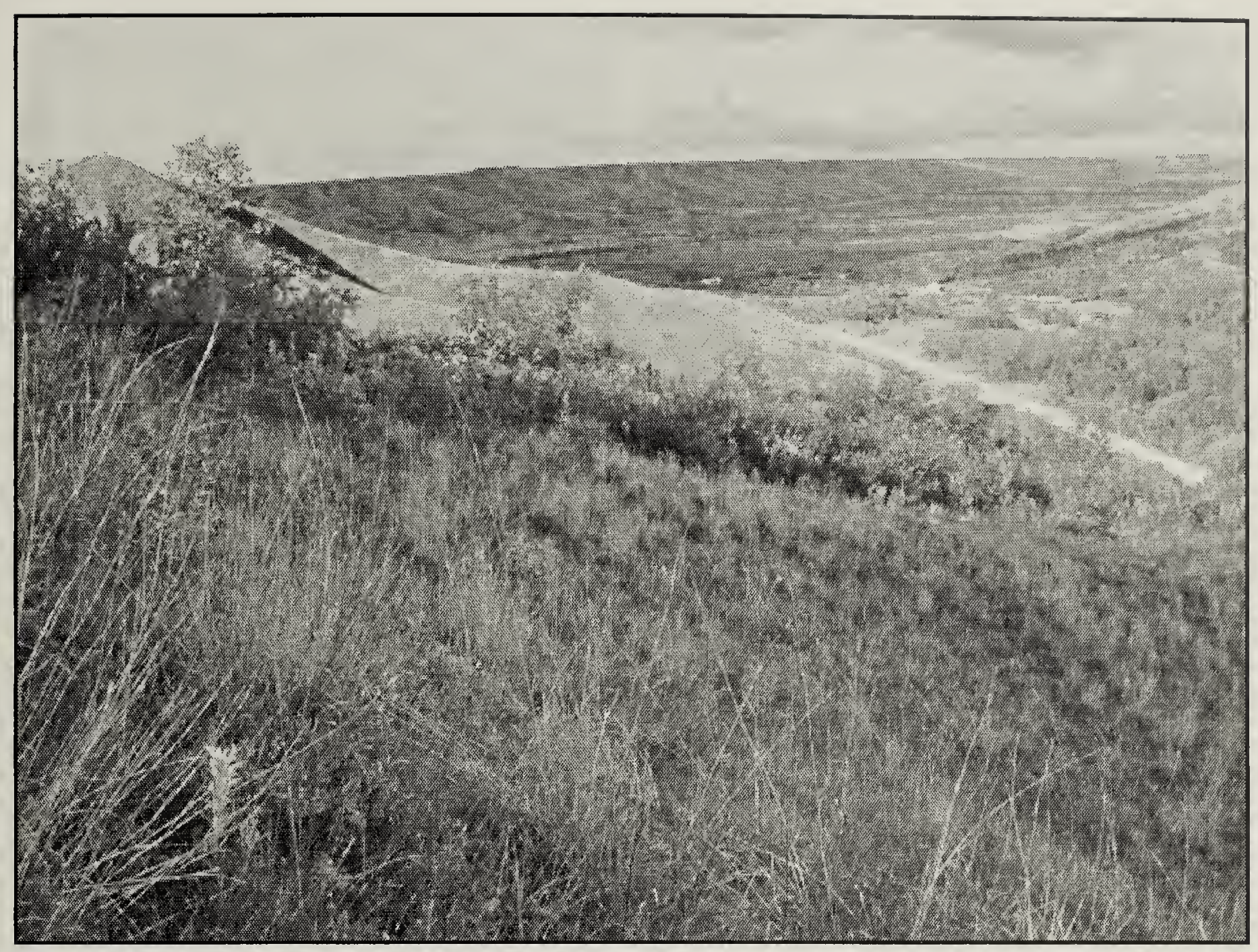

Figure 7. Tallgrass prairie in the foreground on an upper east-facing slope in the Kahkewistahaw Hills on the south side of the Qu'Appelle Valley. The old stems and clumps of Big Bluestem from the previous year are obvious and a plant of Great Plains Indian Paintbrush is evident in the lower left.

P.M. Catling

albidus), and American Pasqueflower or Prairie Crocus (Pulsatilla patens ssp. multifida). Based on this composition, the slope sites appear to be a distinctive intergrading type of tallgrass prairie.

At the top of the slopes, the tallgrass prairie was replaced by either a band of Northern Bedstraw (Galium boreale) and thickets of Saskatoon (Amelanchier alnifolia), or by Fescue prairie and Aspen Parkland with glades dominated by Hall's Fescue (Festuca hallii) and groves of Aspen-Poplar.

Other frequent spring- and early summer-blooming plants in both types of tallgrass prairie are Bastard-Toadflax (Comandra umbellata ssp. umbellata),
Rough Fleabane (Erigeron asper), American Licorice (Glycyrrhiza lepidota) and Boreal Sweet-Vetch (Hedysarum boreale ssp. boreale). These are all common, wide-ranging species of northern grasslands, Aspen Parkland, and vegetation zones transitional to the southern boreal forest.

A number of plant species that are rare in Saskatchewan 15, 22 are associated with the tallgrass prairie remnants that we have seen, either in the region of Whitewood or along the Souris River. Examples include forbs such as Eastern Yellow Star-grass (Hypoxis hirsuta, Figure 9), Stemless Locoweed (Oxytropis lambertii), Closed Bottle Gentian (Gentiana 


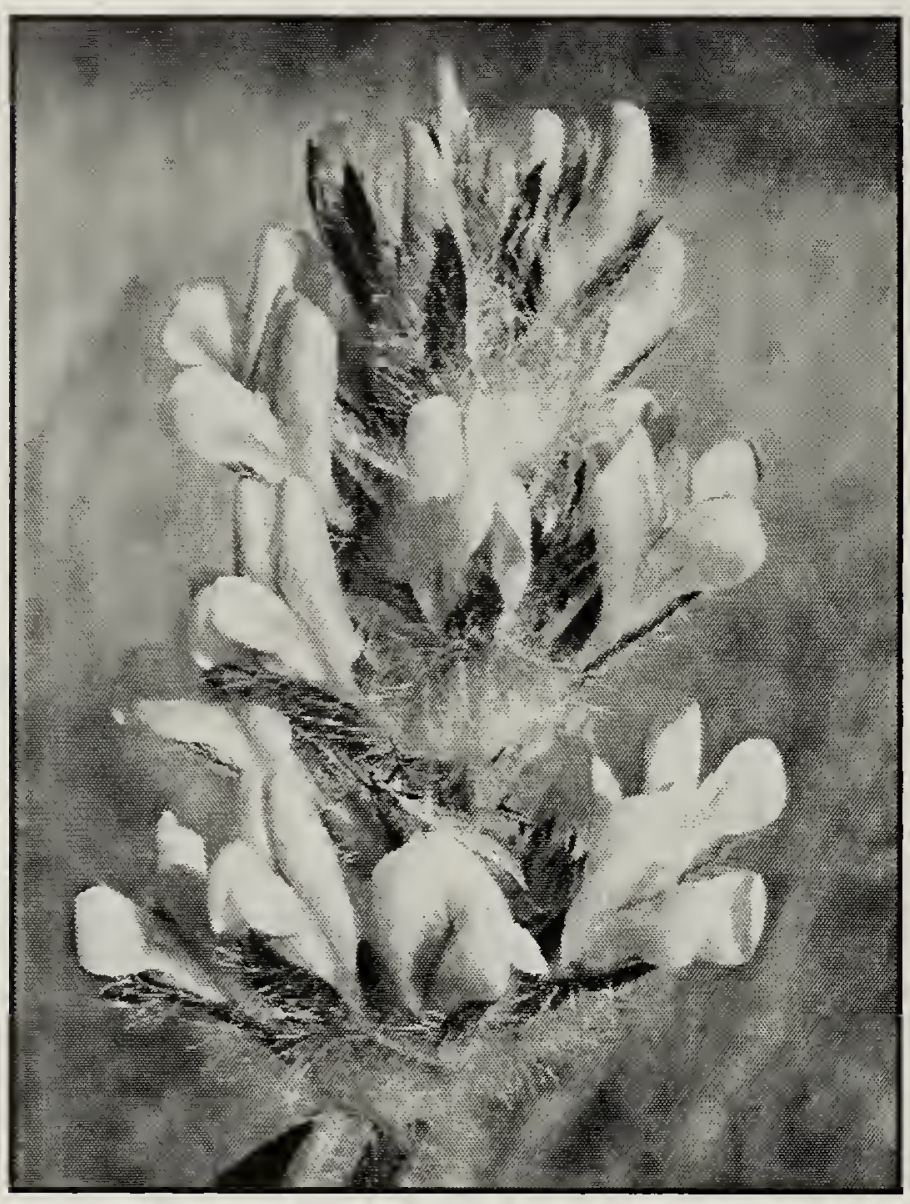

Figure 8. Inflorescence of Large Indian-Breadroot in the Qu'Appelle valley, June 2005. The roots of this plant are edible (cooked or raw) and it is one of several native plants on the prairie with some economic potential.

P.M. Catling

andrewsii var. dakotica), Whorled Milkweed (Asclepias verticillata), and Whorled Milkwort (Polygala verticillata var. isocycla), and grasses, including the characteristic Big Bluestem (Andropogon gerardii), Side-oats Grama (Bouteloua curtipendula), Yellow Indian Grass (Sorghastrum nutans) and Wand Panic Grass (Panicum virgatum).

\section{Discussion}

The tallgrass prairie, characteristic of moister sites, would be the first kind of prairie to be replaced by trees after cessation of fire. Nevertheless the high frequency of mixedgrass prairie in the surviving remnants suggests that at the time of settlement it was this kind of prairie that predominated on the rolling plateau between the river valleys with

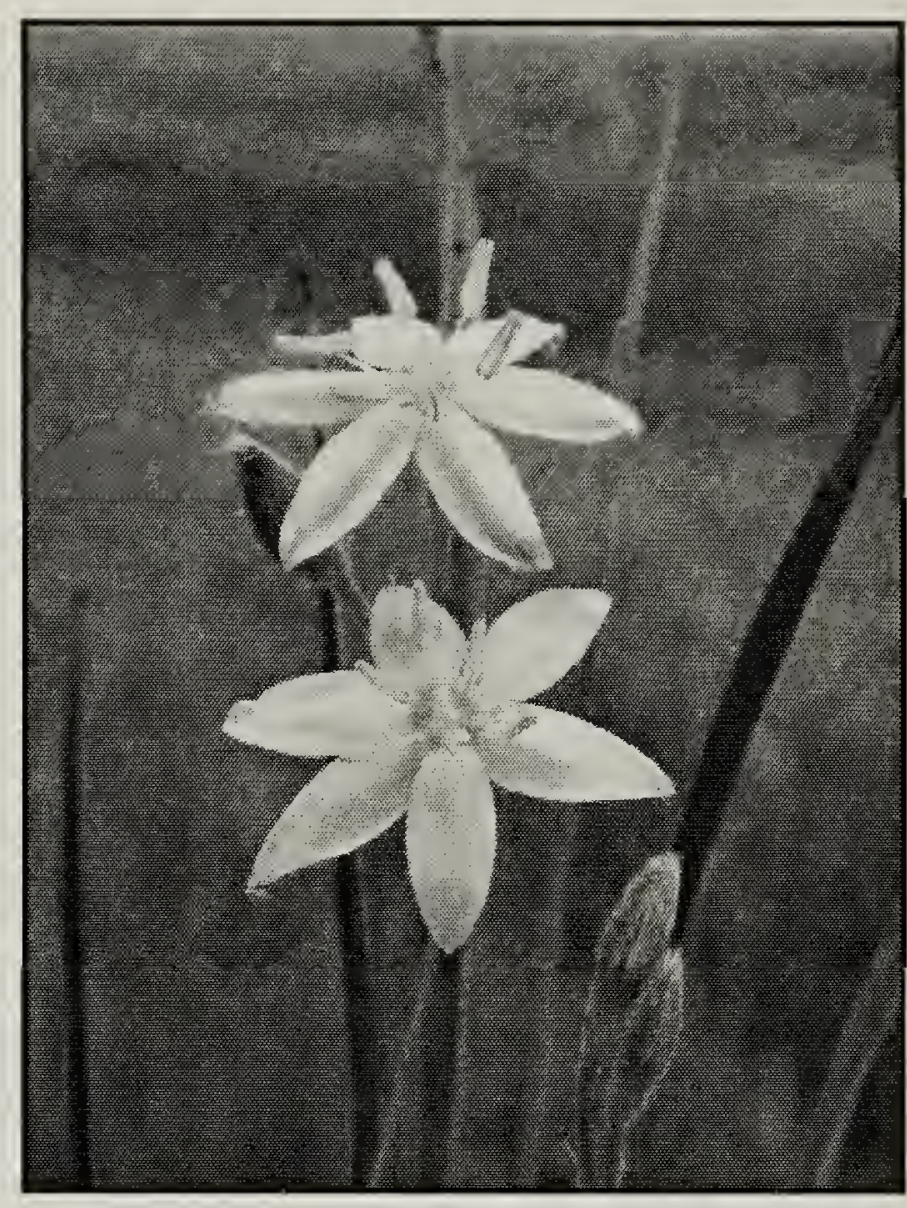

Figure 9. Eastern Yellow Star-grass, (north of Whitewood, June 2005) a rare plant in Saskatchewan and a characteristic species of the tallgrass prairie region.

P.M. Catling

tallgrass prairie in isolated and infrequent patches. In the region of Whitewood, and likely elsewhere in southeastern Saskatchewan, tallgrass prairie was probably most frequent along the slopes of larger river valleys (Figure 10). The slope sites appear to be a distinctive intergrading type of tallgrass prairie with a relatively high diversity associated with the moisture gradient. The plant association includes many species that are characteristic of the drier mixedgrass prairie farther west. A transition upslope from mesic tallgrass prairie to drier tallgrass prairie to mixedgrass prairie with Aspen Poplar parkland and Fescue prairie on top of the slope is probably a result of a moisture gradient. Water availalability would be less on the upper slope than on the top or on the 


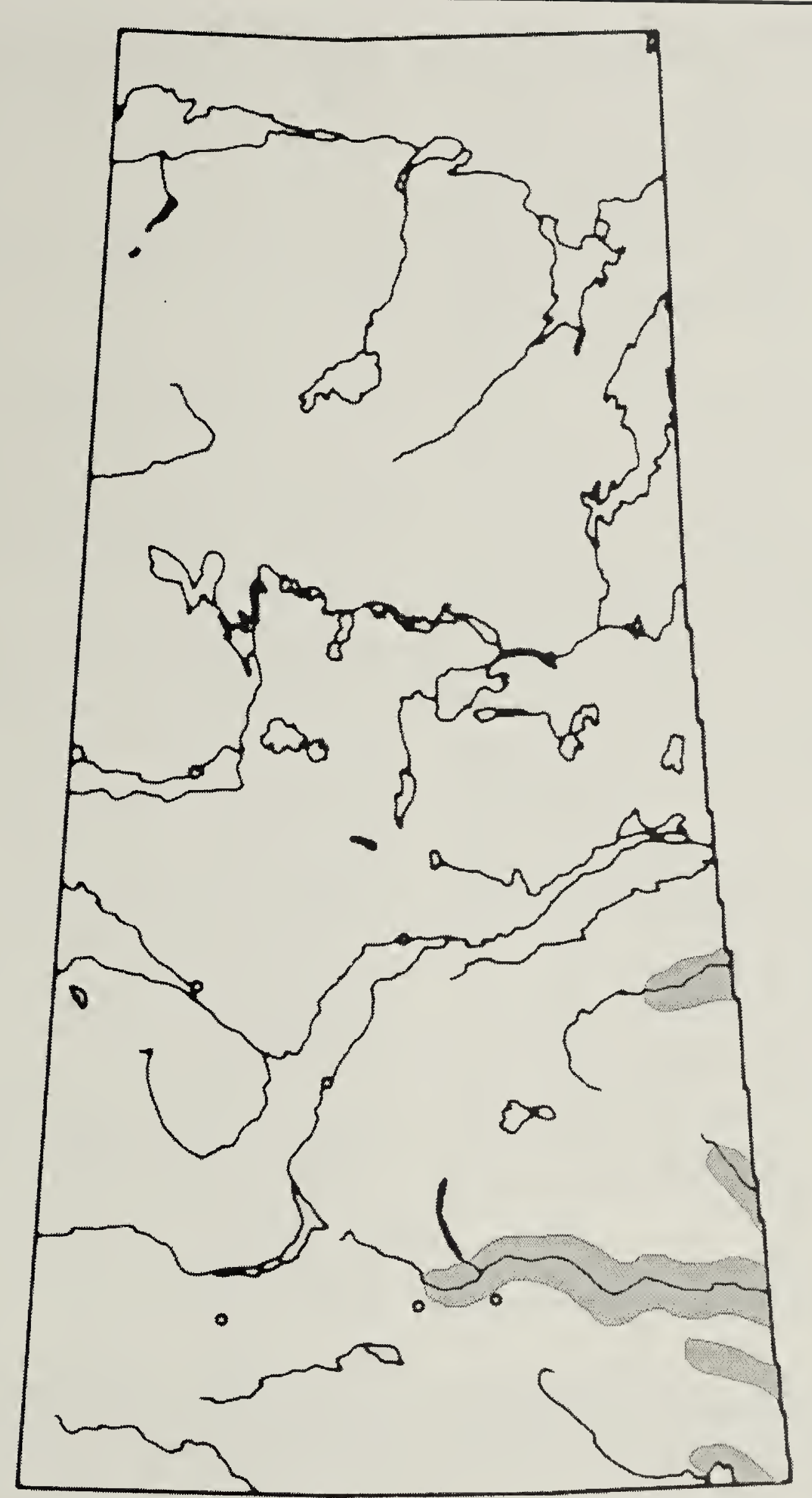

Figure 10. Map of Saskatchewan, showing the likely distribution of more or less continuous tallgrass prairie (shaded areas along rivers in the southeast) in pre-settlement times. The map is based on the distribution of Big Bluestem ${ }^{22}$, tallgrass prairie associated insects ${ }^{14}$ and field survey. Within the shaded region tallgrass prairie may have been more or less continuous but probably occupied much less than $10 \%$ of the shaded areas. There may also have been scattered, isolated occurrences of tallgrass prairie near to these shaded areas. 
lower slope. The tallgrass prairie was probably once much more extensive downslope and existed where there are now extensive slope forests. These tallgrass prairie sites also contain a number of plant species that are rare in Saskatchewan and more study is required to understand and protect their biodiversity.

\section{Acknowledgements}

Vern Harms and Jim Romo of the University of Saskatchewan and Bill Cody of Agriculture and Agri-Food Canada, and an anonymous reviewer made valuable comments. Blaine Coleman and George Chopping of Whitewood contributed historical materials and assisted with finding prairie sites. Anna Leighton provided a very helpful review of the manuscript.

1. ANSTEY, T.H. 1986. One hundred harvests. Research Branch, Agriculture Canada 1886 - 1986. Research Branch, Agriculture Canada, Historical Series No. 27.

2. BAILEY, R.G. 2001. North American ecoregion map.

www.fs.fed.us/institute/ecoregions/na_map.html

3. BIRD, R.D. 1927. A preliminary ecological survey of the district surrounding the entomological station at Treesbank, Manitoba. Ecology 11: 359-384.

4. BIRD, C.D. 1930. Biotic communities of the aspen parkland of central Canada. Ecology 8: 359-384.

5. CANADIAN BIODIVERSITY INFORMATION FACILITY. 2003. Regal Fritillary, Speyeria idalia. [Online] http://linuxgurrl.agr.gc.ca/mapdata/itis/ itisfeaturexml.php

6. CATLING, P.M., V.R. CATLING and S.M. MCKAY-KUJA. 1992. The extent and floristic composition of the Rice Lake Plains based on historical records. Canadian Field-Naturalist 106(1): 73-86.
7. COMMISSION FOR ENVIRONMENTAL COOPERATION. 1997. Ecological regions of North America - toward a common perspective. Commission for Environmental Cooperation, Montreal, Quebec. www.epa.gov/wed/pages/ ecoregions/na_eco.htm

8. COUPLAND, R.T. 1961. Reconsideration of grassland classification in the northern Great Plains of North America. Journal of Ecology 49(1): 135-167.

9. ECOLOGICAL STRATIFICATION WORKING GROUP. 1995. A national ecological framework for Canada. Agriculture and Agri-Food Canada, Research Branch, Centre for Land and Biological Resources Research and Environment Canada, State of the Environment Directorate, Ecozone Analysis Branch, Ottawa/Hull. Report 125 pp. And national map 1:7,500,000 scale.

10. ENVIRONMENT CANADA. 1999. Prairie White Fringed-Orchid. [Online] http:// www.speciesatrisk.gc.ca/Species/English/ SearchDetail.cfm? Species $I D=200$

11. ENVIRONMENT CANADA. 1999. Small white lady's-slipper. [Online] http:// www.speciesatrisk.gc.ca/Species/English/ SearchDetail.cfm?Species $I D=193$

12. ENVIRONMENT CANADA. 1999. Greater prairie chicken: recovery plan executive summary. [Online] http://www.cws-scf.ec.gc.ca/ es/prachi_e.html

13. ENVIRONMENT CANADA. 2004. Conservation of Canadian prairie grasslands tallgrass prairie. [Online] http://www.mb.ec.gc.ca/ nature/whp/prgrass/df03s32.en.html

14. HAMILTON, K.G.A. 2005. Bugs reveal an extensive, long-lost northern tallgrass prairie. Bioscience 55(1): 49-59.

15. HARMS, V.L. 2003. Checklist of the vascular plants of Saskatchewan and the provincially and nationally rare native plants in Saskatchewan. University of Saskatchewan, Saskatoon.

16. HOWE, H.F. 1994. Managing species diversity in tallgrass prairie: assumptions and implications. Conservation Biology 8(3): 691- 704.

17. KARTESZ, J.T. and C.A. MEACHUM. 1999. Synthesis of the North American flora. Version 1.0. Biota of North America Program, University of North Carolina, Chapel Hill. 
18. KNAPP, A.K., J.M. BLAIR, J.M. BRIGGS, S.L. COLLINS, D.C. HARTNETT, L.C. JOHNSON and E.G. TOWNE. 1999. The keystone role of Bison in North American tallgrass prairie. Bioscience 49(1): 39-50.

19. KUCERA, C.L. 1992. Tall grass prairie. Pp. 227-268 in R. T. Coupland, ed. Natural grasslands: introduction and western hemisphere. Ecosystems of the world 8a. Elsevier, New York.

20. KUCHLER, A.W. 1964. Potential natural vegetation of the coterminous United States. American Geographical Society (Washington, D.C.) Special Publication 36.

21. LEVIN, M.H. and G.M. KELEHER. 1969. Vegetation of a prairie near Winnipeg, Manitoba. Canadian Field-Naturalist 83: 113-122.

22. MAHER, R.V., G.W. ARGUS, V.L. HARMS and J.H. HUDSON. 1979. The rare vascular plants of Saskatchewan. National Museum of Natural Sciences Syllogeus no. 20. 55 pp. + maps.

23. RADENBAUGH, T.A. 1998. Saskatchewan's prairie plant assemblages: a hierarchical approach. Prairie Forum 23(1): 31-47.

24. REDMANN, R.E. 1972. Plant communities and soils of an eastern North Dakota prairie. Bulletin Torrey Botonical Club 99: 65-76.

25. RICKETTS, T.H. et al. 1999. Terrestrial ecoregions of North America: A conservation Assessment. Washington (DC). Island Press.

26. RODGER, L. 1998. Tallgrass communities of southern Ontario: a recovery plan. WWF Canada.
27. SAMSON, F. B., and F. L. KNOPF. 1994. Prairie conservation in North America. BioScience $44: 418-421$.

28. TRAGER, J.C. 1998. An introduction to ants (Formicidae) of the tallgrass prairie. Missouri Prairie Journal (fall 1998): http:// www.npwrc.usgs.gov/resource/1999/ants/ origins.htm

29. USGS Northern prairie wildlife research centre. 2005. Butterflies of North America - Regal Fritillary (Speyeria idalia). [Online]. http:// www.npwrc.usgs.gov/resource/distr/lepid/bflyusa/ usa/80.htm

30. VAUGHAN, D. M., and M. D. SHEPHERD. 2005. Species Profile: Speyeria idalia. In Shepherd, M. D., D. M. Vaughan, and S. H. Black (Eds). Red List of Pollinator Insects of North America. CD-ROM Version 1 (May 2005). Portland, OR. The Xerces Society for Invertebrate Conservation. [Online] http://www.xerces.org/ Pollinator_Red_List/Leps/Speyeria_idalia.pdf

31. WATTS, F.B. 1960. The natural vegetation of the southern Great Plains of Canada. Geographical Bulletin 14: 25-43.

32. WILLIAMS, B.E. 2002. Recognition of western populations of Speyeria idalia

(Nymphalidae) as a new subspecies. Journal of the Lepidopterists' Society 55(4):144-149.

33. WORLD WILDLIFE FUND. 2001. Northern tall grasslands (NA0812). [Online] http:// www.worldwildlife.org/wildworld/profiles/terrestrial/ na/na0812_full.html\#con_stat

"Cocoa bushes bloom twice a year, and their pollination depends on biting midges (Ceratopongonidae) and gall midges (Cecidomyiidae). Despite a domestication process that began with the Aztecs thousands of years ago, most cocoa bushes still require the services of their wild pollinators....Compost and rotting banana stems must be strewn between the cocoa bushes to provide midge mommies with maggot nurseries. Moldy fallen fruit are left on the ground, as adult gall midges like to eat fungus spores."

- Peter Bernhardt

The Rose's Kiss: A Natural History of Flowers, p.144-145. 